\title{
Isolation, Screening and Characterization of Chitinase Producing Fungi from Apple Orchards of Shimla and Kinnaur District, India
}

\author{
Nirja Thakur ${ }^{1 *}$, Rakesh Gupta ${ }^{2}$, Amarjit K. Nath ${ }^{1}$, Anjali Chauhan ${ }^{3}$, \\ Manisha Thakur ${ }^{1}$, R.K. Dogra ${ }^{4}$ and Himanshu Pandey ${ }^{1}$ \\ ${ }^{1}$ Department of Biotechnology, ${ }^{2}$ College of Horticulture, \\ ${ }^{3}$ Department of Soil Science \& Water Management, ${ }^{4}$ Department of Fruit Science, \\ Dr Y S Parmar, UHF, Nauni, Solan (H.P.), India \\ *Corresponding author
}

\section{A B S T R A C T}

\section{Keywords}

Soil, Chitinase, Colloidal chitin 18S rRNA sequencing

Article Info

Accepted: 12 December 2018 Available Online: 10 January 2019

\begin{abstract}
Aims of present study were to isolate and characterize chitinase producing fungi from soil samples of apple orchards of Shimla and Kinnaur district of Himachal Pradesh. The soil samples were collected aseptically and subjected to serial dilution to isolate the fungal strains. Total nine morphologically different fungi were isolated and screened for their chitinolytic activity in colloidal chitin incorporated media through zone assay. The isolates were screened based on the size of the zone formed. Best chitinase producers were subjected 18S ribosomal RNA sequencing. After molecular characterization of two isolates, they were identified as Alternaria brassicicola strain and Pencillium sp. isolate. A novel strain, Acinetobacter ASK18, a gram-negative, motile organism was identified. These isolates would further be subjected to purification of the enzyme produced and hence could be evaluated as effective biocontrol agents against pathogenic bacteria and fungi.
\end{abstract}

\section{Introduction}

Chitin is considered as the second most abundant natural polymer after cellulose with the structural unit of $\mathrm{N}$-acetylglucosamine linked by $\beta-1,4$ bonds. It is present in the cell wall of higher fungi, exoskeletons of insect, and shells of crustaceans (Patil et al., 2000 and Svitil et al., 1997). Chitinolytic enzymes are able to lyse the cell wall of many fungi. The microorganisms that produce these chitynolytic enzymes are able to destroy the cell wall of many fungi and insects. So, these microorganisms are capable of eradicating fungal diseases that are a problem for global agricultural production. Being more ecofriendly and cost effective method as compared to the chemical method for disease eradication like use of fungicides and various pesticides, the enzymatic method can be adopted as an alternative. Chitinases (EC 3.2.1.14) are the enzymes that are produced by several bacteria, actinomycetes, fungi and also by higher plants (Shanmugaiah et al., 2008; Ajit et al., 2006; Akagi et al., 2006; Matsushima et al., 2006 and Viterbo et al., 
2001). The presence of chitinolytic microbes indicates the availability of chitin in the soil. Chitinases also play a major role in many areas such as the production of single cell protein, growth factors (Ferrer et al., 1996 and Felse et al., 2000), mosquito control, a biocontrol agent of fungal pathogens, and isolation of fungal protoplasts (Prabavathy et al., 2006 and Chang et al., 2007). Thus, the importance of microbial chitinase production has increases because on the one hand, it reduces environmental hazards and on the other hand increases production of industrially important value-added products. Thus, the present study has been narrowed on isolation, screening and characterization of chitinase producing fungi from soil samples collected from Himachal Pradesh.

\section{Materials and Methods}

\section{Chemicals}

The materials, media, reagents used for this study were procured from Sigma-aldrich, SRL and Hi-Media, India.

\section{Collection of soil samples}

Shimla and Kinnaur of Himachal Pradesh were surveyed and selected for sample collections. From each district, further five sites from Shimla district (viz. Craignano, Kotkhai, Narkanda, Theog and Jubbal) and three sites from Kinnaur district (viz. Sangla, Kalpa and Reckong Peo,) were selected. From each selected site, three subsites (apple orchards) were further selected for the collection of the soil samples. Soil samples were collected from top soil ranging in depth from $10-15 \mathrm{~cm}$ in sterilized polythene bags with the help of sterilized spatula (Singh et al., 2003) and these samples were brought to the laboratory a kept at $4^{\circ} \mathrm{C}$ in refrigerator till further processing. Sample codes were given to each sample.

\section{Preparation of colloidal chitin}

Extrapure chitin powder purchased from HiMedia was used to prepare the colloidal chitin (Mathivanan et al., 1998). Chitin powder $(40 \mathrm{~g})$ was dissolved in $500 \mathrm{ml}$ of concentrated $\mathrm{HCl}$ and continuously stirred at $4^{0} \mathrm{C}$ for one hour and kept overnight. The suspension was added to cold 50\% ethanol with rapid stirring and kept overnight at $25^{\circ} \mathrm{C}$. The precipitate was collected by centrifugation at $10,000 \mathrm{rpm}$ for $20 \mathrm{~min}$ and washed with sterile distilled water until the colloidal chitin became neutral $(\mathrm{pH} 7.0)$. It was freeze dried to powder and stored at $4{ }^{\circ} \mathrm{C}$ until further use.

\section{Isolation of fungi from soil samples}

The soil dilution plate method (Waksman, 1922) was used for isolation of fungi. Soil dilutions were made by suspending $1 \mathrm{~g}$ of soil of each sample in $10 \mathrm{ml}$ of sterile distilled water. Dilutions of $10^{-3}, 10^{-4}$ and $10^{-5}$ were used to isolate fungi in order to avoid overcrowding of the fungal colonies. $1 \mathrm{ml}$ of the suspension of each concentration was added to sterile petri dishes, in triplicates of each dilution, containing sterile Potato Dextrose Agar medium(Dextrose: 20 g/l, Agar: 15 g/l, Potato starch: $4 \mathrm{~g} / \mathrm{l}, \mathrm{pH}: 5.6) .1 \%$ streptomycin solution was added to the medium for preventing bacterial growth, before pouring into petri plates. The plates were then incubated at $28 \pm 2{ }^{\circ} \mathrm{C}$ for $4-7$ days. Fungal growth was observed, purified individually and maintained on PDA slants for further experiments.

\section{Screening of chitinase producing fungi}

The fungal cultures were spotted on the selected colloidal chitin agar media(Colloidal chitin: $5 \mathrm{~g} / 1, \quad \mathrm{KH}_{2} \mathrm{PO}_{4}$ : $2 \mathrm{~g} / \mathrm{l}, \quad \mathrm{MgSO}_{4} .7 \mathrm{H}_{2} \mathrm{O}$ : $0.3 \mathrm{~g} / 1,\left(\mathrm{NH}_{4}\right)_{2} \mathrm{SO}_{4}: 1.4 \mathrm{~g} / \mathrm{l}, \mathrm{CaCl}_{2} \cdot 2 \mathrm{H}_{2} \mathrm{O}: 0.5 \mathrm{~g} / \mathrm{l}$, Bactopeptone: $0.5 \mathrm{~g} / \mathrm{l}$, Urea: $0.3 \mathrm{~g} / \mathrm{l}$, 
$\mathrm{FeSO}_{4} .7 \mathrm{H}_{2} \mathrm{O}: \quad 0.005 \mathrm{~g} / \mathrm{l}, \quad \mathrm{MnSO}_{4} .7 \mathrm{H}_{2} \mathrm{O}:$ $0.0016 \mathrm{~g} / \mathrm{l}, \quad \mathrm{ZnSO}_{4} .7 \mathrm{H}_{2} \mathrm{O}: \quad 0.0014 \mathrm{~g} / \mathrm{l}$, $\mathrm{CoCl}_{2} .2 \mathrm{H}_{2} \mathrm{O}: 0.002 \mathrm{~g} / \mathrm{l}$, Agar: $15 \mathrm{~g} / \mathrm{l}, \mathrm{pH}: 6.0$ ) and the plates were incubated at $28^{\circ} \mathrm{C}$ for 5 days. Development of halo zone around the colony was considered as positive for chitinase enzyme production.

\section{Characterization of fungal isolates}

\section{Identification of chitinolytic fungi}

The isolates were identified through their morphological characters by preparing slides with lactophenol cotton blue stain and the partial nucleotide sequence of $18 \mathrm{~S}$ ribosomal RNA (rRNA) was determined using universal ITS primers. The $18 \mathrm{~S}$ rRNA sequence was compared to the sequences in the genbank nucleotide database by using Basic Local Alignment Search Tool (BLAST).

Isolation of genomic DNA for 18SrRNA sequencing and polymerase chain reaction amplification

Total genomic DNA of all the isolates was extracted by phenol-chloroform method according to Sambrook et al., (1989). The concentration and purity of the DNA were estimated by agarose gel electrophoresis on ultraviolet (UV) transilluminator.

Molecular identification of the isolates was carried by $18 \mathrm{~S}$ rRNA sequencing using the universal forward and reverse primer: ITS15'TCCGTAGGTGAACCT TGCGG 3' and ITS4- 5'TCCTCCGCT TAT TGATATGC 3' respectively using a polymerase chain reaction (PCR) (Applied Biosystems, USA). The PCR amplification was performed with denaturation $\left(95^{\circ} \mathrm{C} ; 30 \mathrm{~s}\right)$, annealing $\left(54{ }^{\circ} \mathrm{C}\right.$; $30 \mathrm{~s})$, extension $\left(72^{\circ} \mathrm{C} ; 5 \mathrm{~min}\right)$ followed by a final extension $\left(72{ }^{\circ} \mathrm{C} ; 5 \mathrm{~min}\right)$. The PCRamplified product was analyzed in $2 \%$ agarose gel added with ethidium bromide and $1 \mathrm{~kb}$
DNA ladder followed by UV trans-illuminator documentation. The PCR-amplified sample was sequenced with the same set of primers. Finally, a similarity search for the nucleotide sequence of 18S rRNA gene of the test isolate was carried out using a BLAST search at NCBI.

\section{Results and Discussion}

Chitinase producing fungal strains were isolated from the soil samples from different sites of Shimla and Kinnaur district of Himachal Pradesh. Totally, 9 different fungal strains viz., SCF1.1,

SCF2.1, SKF3.1, SNF1.1, SNF1.2, SNF3.1, KSF1.1, KSF1.2 and KRF3.1 were isolated. These isolates were characterized morphologically and microscopically (Fig. 1 and 2). Out of 9 fungal isolates, 3 isolates were found to produce clear zone when incubated in colloidal chitin-containing media (Fig. 3). Clear zone surrounding the colony indicates chitinase activity to break down chitin compound in medium. These isolates were subjected to identification through sequencing. Universal primer for $18 \mathrm{~S}$ rRNA gene were able to successfully amplify $18 \mathrm{~S}$ rRNA gene of selected fungal isolates and produced amplicons of expected size i.e. 570 bp (Fig. 4 and 5). On the basis of results obtained from 18S rRNA gene analysis and in addition to $\mathrm{G}+\mathrm{C}$ content analysis, the selected two chitinase producing fungal isolates i.e. SNF1.1 and SNF3.1 were found to belong to two genera i.e. Alternaria and Penicillium. Chitinases are widely distributed in many filamentous fungi including Trichoderma, Oenicillium, Penicillium, Lecanicillium, Neurospora, Mucor, Beauveria, Lycoperdon, Aspergillus, Myrothecium, Conidiobolus, Metharhizium, Stachybotrys and Agaricus (Matsumoto et al., 2006; Duo-Chuan, 2006 and Hartl et al., 2012). 
Fig.1

SCFl.1

SCF2.1

SKF3.1
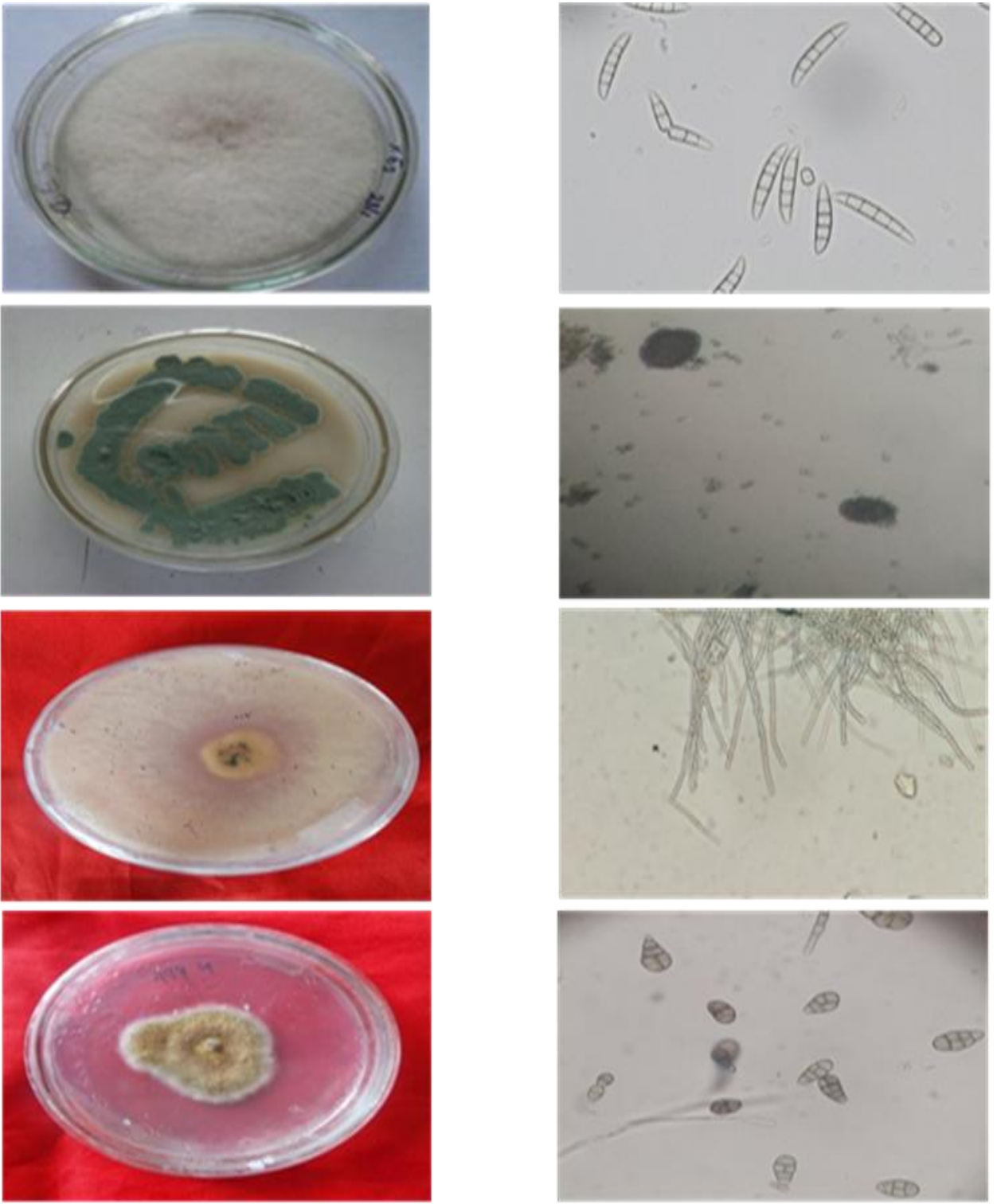

SNF1.1
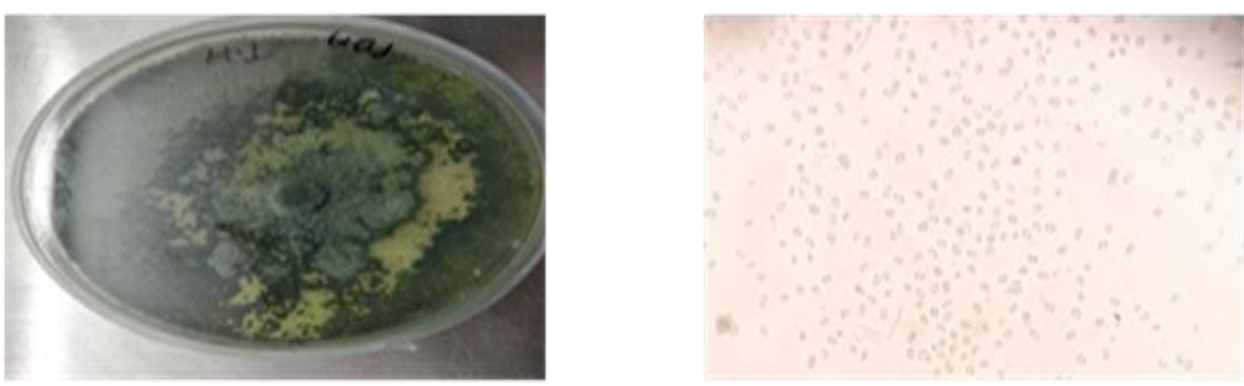

Fig.1 Different colony and microscopic characteristics of fungal isolates 
Fig.2

SNF3.1

KSF1.1

KSF1.2
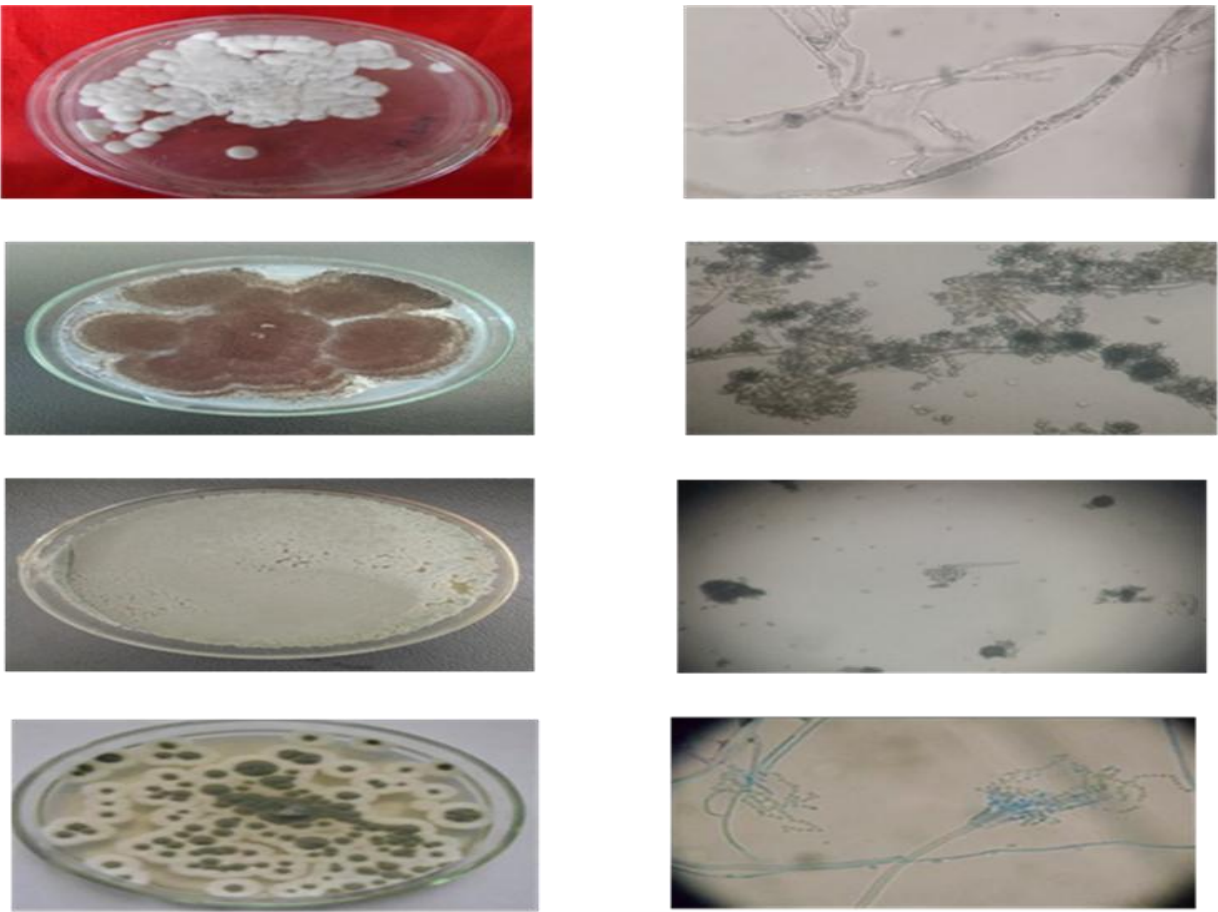

Fig.2 Different colony and microscopic characteristics of fungal isolates

Fig.3
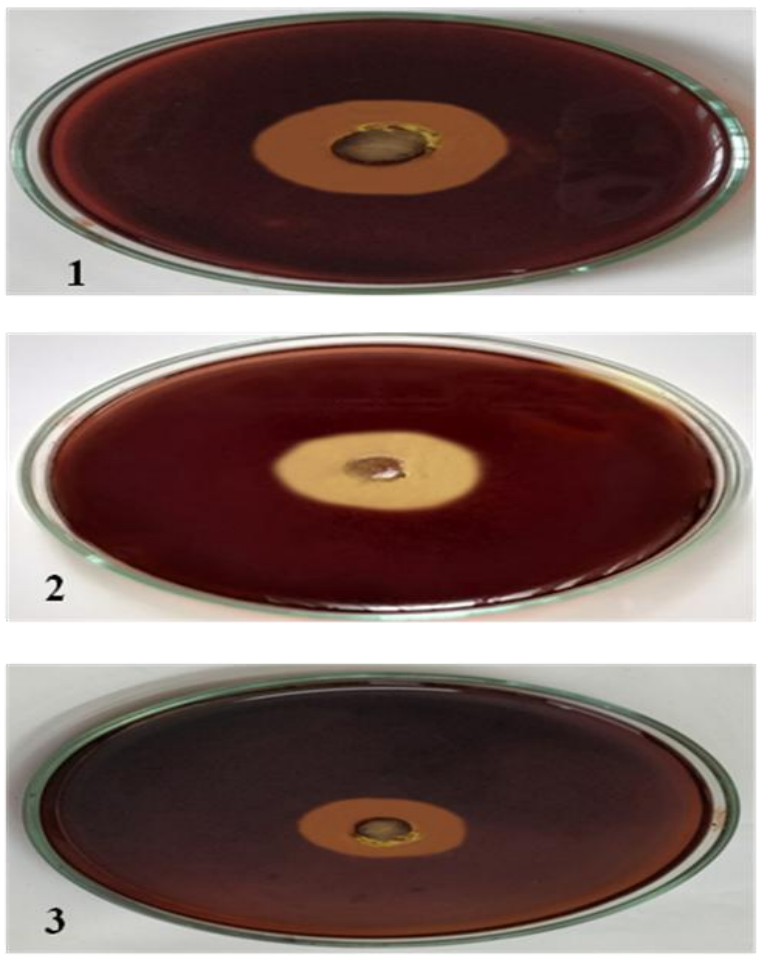

is shown on colloiodal chitin agar medium(1-SNF1.1; 2-SN 
Fig.4

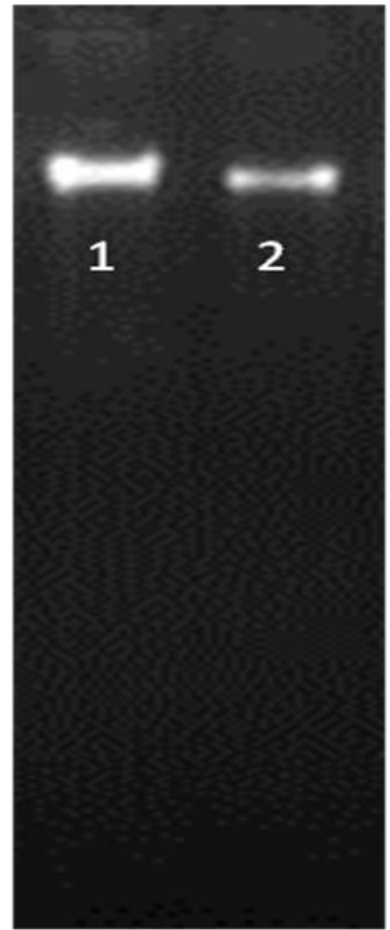

Fig.4: Gel image showing genomic DNA extracted from two chitinase producing fungal isolates.

Lane 1: SNF 1.1,Lane 2: SNF3.1

Fig.5

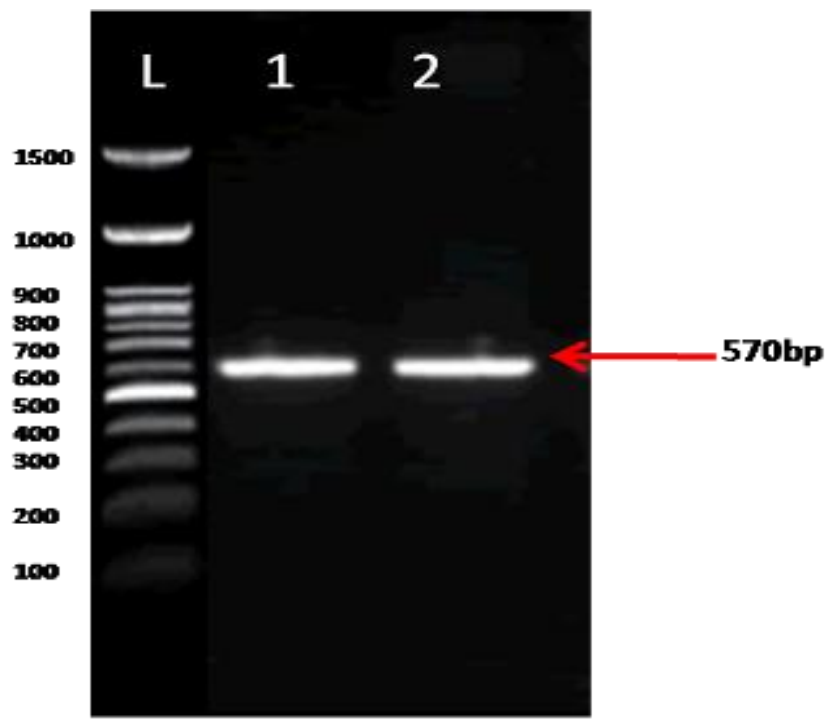

Fig.5: Amplicons of $18 \mathrm{~s}$ rma gene of selected two chitinase producing fungal isolated.Lane L:100 bp DNA badder; Lane 1:SNF1.1;Lane 2: SNF3.1. 
In conclusion, chitin is a versatile and promising biopolymer with numerous industrial, medical and commercial uses. Therefore, the present study was based to isolate chitinase producing fungi so that they can used as an effective biocontrol agents and other potential uses can be exploited from them in near future.

\section{References}

Ajit NS, Verma R and Shanmugam V. 2006. Extracellular chitinases of fluorescent pseudomonads antifungal to Fusarium oxysporum f. sp. dianthi causing carnation wilt. Current Microbiology 52(4): 310-6.

Akagi K, Watanabe J, Hara M, Kezuka Y, Chikaishi E and Yamaguchi T. 2006. Identification of the substrate interaction region of the chitin-binding domain of Streptomyces griseous chitinase Current Journal of Biochemistry 139(3): 483-93.

Chang WT, Chen YC and Jao CL. Antifungal activity and enhancement of plant growth by Bacillus cereus grown on shellfish chitin wastes. Bioresource Technology 98(6): 1224-30.

Duo-Chuan L. 2006. Review of fungal chitinases. Mycopathologia 161(6): 345-360.

Felse PA and Panda T. Production of microbial chitinases-a revisit.2000. Bioprocess Engineering 23(2):127-34.

Ferrer J, Paez G, Marmol Z, Ramones E, Garcia H and Forster CF. 1996. Acid hydrolysis of shrimp shell waste and the production of single cell protein from the hydrolysate. Bioresource Technology 57(1): 55-60.

Hartl L, Zach S and Seidl-Seiboth V. 2012. Fungal chitinases: Diversity, mechanistic properties and biotechnological potential. Applied
Microbiology and Biotechnology 93 (2):533.

Mathivanan N, Kabilan V and Murugesan K. 1998. Purification, characterization and antifungal activity of chitinase from Fusarium chlamydosporum, a mycoparasite to groundnut rust, Puccinia arachidis. Canadian Journal of Microbiology 44(7): 646-651

Matsumoto KS. 2006. Fungal chitinases. Advances in agricultural and food Biotechnology. 6: 289-304.

Matsushima R, Ozawa R, Uefune M, Gotoh T and Takabayashi J. 2006. Intraspecies variation in the kanzawa spider mite differentially affects induced defensive response in lima bean plants. Journal of Chemical Ecology 32(11): 2501-12.

Patil RS, Ghormade VV and Deshpande MV. 2006. Chitinolytic enzymes: an exploration. Enzyme Microbial Technology, 26(7): 473-83.

Prabavathy VR, Mathivanan N, Sagadevan E, Murugesan $\mathrm{K}$ and Lalithakumari D. 2006. Intra-strain protoplast fusion enhances carboxymethyl cellulase activity in Trichoderma reesei. Enzyme Microbial Technology 38(5): 719-23.

Sambrook JEF, Fritsch and Maniatis T. 1989. Molecular Cloning: A Laboratory Manual. Cold Spring Harbor Press, Cold Spring Harbor, New York.

Shanmugaiah V, Mathivanan N, Balasubramanian $\mathrm{N}$ and Manoharan P.2008. Optimization of cultural conditions for production of chitinase by Bacillus laterosporous isolated from rice rhizosphere soil. African Journal of Biotechnology 7: 2562-8.

Singh BK, Walker A, Morgan JAW and Wright DJ. 2003. Effect of soil $\mathrm{pH}$ on the biodegradation of chlorpyrifos and isolation of a chlorpyrifos- 
degrading bacterium. Applied Environmental Microbiology. 69: 5198-5206.

Svitil AL, Chadhain S, Moore JA and Kirchman DL. 1997. Chitin degradation proteins produced by the marine bacterium Vibrio harveyi growing on different forms of chitin. Applied Environmental Microbiology 63(2): 408-13.
Viterbo A, Haran S, Friesem D, Ramot O and Chet I.2001. Antifungal activity of a novel endochitinase gene (chit36) from Trichoderma harzianum Rifai TM. FEMS Microbiology Letters 200(2): 169-74.

Waksman SA. 1922. A method for counting the number of fungi in the soil. Journal of bacteriology 7(3): 339.

\section{How to cite this article:}

Nirja Thakur, Rakesh Gupta, Amarjit K. Nath, Anjali Chauhan, Manisha Thakur, R.K. Dogra and Himanshu Pandey. 2019. Isolation, Screening and Characterization of Chitinase Producing Fungi from Apple Orchards of Shimla and Kinnaur District, India. Int.J.Curr.Microbiol.App.Sci. 8(01): 1556-1563. doi: https://doi.org/10.20546/ijcmas.2019.801.163 